\title{
New records of marine eels (Teleostei: Anguilliformes) from Brazilian waters
}

\author{
Alfredo Carvalho Filho ${ }^{1,3}$ \& Maria Isabel G. Paiva ${ }^{2}$ \\ ${ }^{1}$ Fish-Bizz Ltda. Rua Maria Garcez, 39, São Paulo, SP, 05424-070, Brazil \\ ${ }^{2}$ Projeto TAMAR-ICMBio. Avenida do Farol Garcia D’Ávila, s/n, Praia do Forte, Mata de São João, BA, 48280-000, Brazil \\ ${ }^{3}$ Corresponding author. E-mail: alfie@telnet.com.br
}

\begin{abstract}
Two species of different families belonging to the order Anguilliformes have their ranges extended in the southwestern Atlantic: the chlopsid Chlopsis dentatus (Seale, 1917) from Rio de Janeiro and the muraenid Gymnothorax maderensis (Johnson, 1862) from Bahia. The new records extend the distribution of these species south along the Brazilian coastline. Morphometric data of the specimens are provided and compared to data from the literature.
\end{abstract}

Key words: Southwestern Atlantic; Chlopsidae; Muraenidae; Chlopsis dentatus; Gymnothorax maderensis; range extension

The order Anguilliformes includes more than 800 recognized species in 15 families and about 140 genera. All but three families, Anguillidae, Protanguilidae, and Heterenchelidae, occur in the southwestern Atlantic. About 105 species are reported from Brazilian marine waters, of which the most species-numerous families are Ophichthidae (26 species), Congridae (25 species), and Muraenidae (17 species including Gymnothorax maderensis) (BÖHLKE 1989; Menezes et al. 2003; Melo et al. 2009; PAIVA 2011; BONECKER et al. 2014).

Deep-sea research off Brazil has been sparse, but recent exploratory fishing efforts have resulted in several new records, range extensions, and descriptions of new species from the southwestern Atlantic (e.g., BERNARDES et al. 2005; MincARone et al. 2008; CARVALHo-Filho et al. $2009,2010,2011)$. Several of these records are of the results of a research project by the Projeto TAMAR (Projeto Tartaruga Marinha, the Brazilian environmental institution that protects and study the sea turtles) team, which aims to evaluate the efficiency of the circle hook in pelagic and bottom longline fisheries (CARVALHO-FILHO et al. 2009). In this paper, we provide new records for two anguilliform species in the southwestern Atlantic: the chlopsid Chlopsis dentatus (Seale, 1917), extending its range southwards to Rio de Janeiro state; and the muraenid Gymnothorax maderensis (Johnson, 1862), extending its range to Bahia and Espírito Santo states.
The specimen of Chlopsis dentatus was collected in 2010 by a survey team dredging rhodolith banks off the Rio de Janeiro coast. Two specimens of Gymnothorax maderensis were collected in 2012 by the deep-sea fishing exploratory crew of the TAMAR Project off Bahia. The specimens were fixed in formalin, preserved in ethanol $70 \%$, and deposited at MZUSP collection. Another seven specimens of $G$. maderensis that we studied were also collected from Bahia, by the Programa de Avaliação do Potencial Sustentável de Recursos Vivos na Zona Econômica Exclusiva (REVIZEE); these are deposited at MNRJ collection. Measurements were taken with a digital caliper to tenths of millimeters (mm); measurements between $150 \mathrm{~mm}$ and $300 \mathrm{~mm}$ were taken with a manual caliper to the nearest tenth of $\mathrm{mm}$; over $300 \mathrm{~mm}$ with a ruler to the nearest tenth of $\mathrm{mm}$. Length of specimens are given in total length (TL) and head length is abbreviated as HL. Institutional abbreviations follow SABAJ-PÉREZ (2014). Systematics of Anguilliformes follows BETANCUR et al. (2014).

Family Chlopsidae Rafinesque, 1810

Chlopsis dentatus (Seale, 1917) (Figure 1)

Mottled False Moray (English); Congro-mirim (Brazilian Portuguese) Anguilla moteada, Morena falsa dientona (Spanish).

Morphometric data are given in Table 1. The Chlopsidae are small eels, not longer than $30 \mathrm{~cm}$, with stout to moderately elongate, compressed body with the anus slightly before mid-body. The genus Chlopsis is characterized by the absence of pectoral fins; origin of the dorsal fin over or slightly behind gill opening, rictus near posterior margin of eye; anterior nostril tubular, near tip of snout; presence of two series of vomerine teeth; and the lower lip without a downturned flange. Chlopsis dentatus is distinguished from all its congeners by its banded mottled color pattern. All other species known to date are bicolored to some degree. Chlopsis bicolor Rafinesque, 1810 from the Western Atlantic presents a sharply defined bicolored pattern, and C. dentatus also differs by the position of the origin of the 


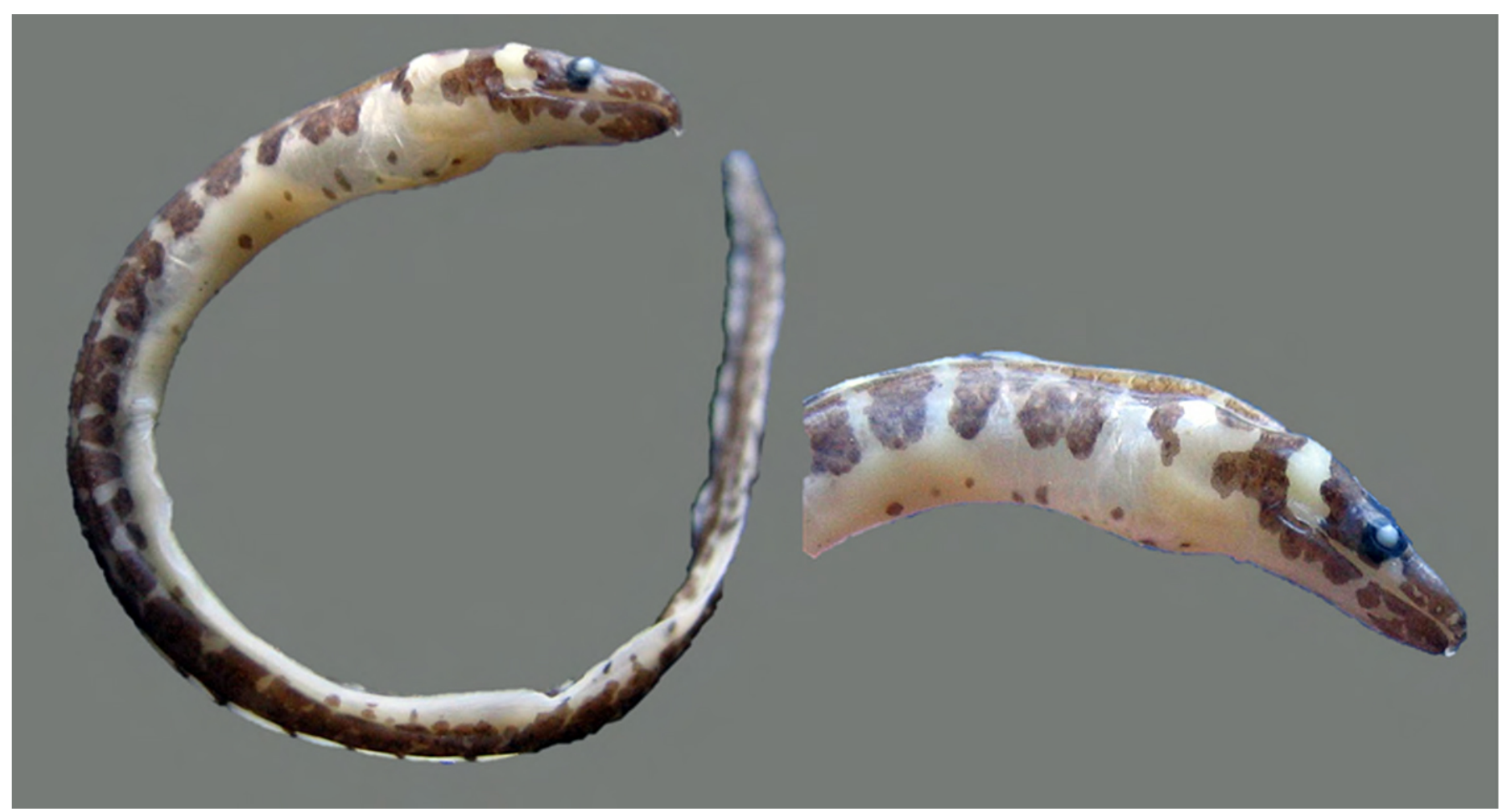

Figure 1. Chlopsis dentatus, MZUSP 119852, 85.2 mm TL, with close of the head. Photos by A. Carvalho-Filho.

dorsal fin, distinctly behind the gill opening in C. bicolor and slightly behind the gill opening in $C$. dentatus. The only Eastern Atlantic species, C. olokun (Robins \& Robins, 1966), is a pale, uniformly tan-colored species with white belly, where the bicolored effect is weakly developed. Furthermore, it has the dorsal fin origin located above the gill opening. Our specimen agrees with the diagnostic and specific characters of $C$. dentatus and has the same coloration as described by SeAle (1917), BÖHLKe \& SMith (1968), and SMith (1989a). The snout length presented by SMITH (1989a) seems to be not accurate (12-14\% of head length) when compared to BÖHLKE \& SMITH (1968). The identification of the species follows SEALE (1917), RoBINS \& RoBINS (1967), BÖHLKE AND SMith (1968), BLACHe (1972), SMith (1989a, 1989b, 2016a), TigHE \& MCCOSKER (2003), and BONECKER et al. (2014).

Material examined: MZUSP 119852 1, $85.2 \mathrm{~mm}$ TL, Campo Peregrino, Station $03\left(23^{\circ} 18^{\prime} \mathrm{S}, 041^{\circ} 17^{\prime} \mathrm{W}\right)$, Bacia de Campos, Campos, Rio de Janeiro, Brazil, collector: F.T.S. Tâmega, depth ca. 100 m, rhodolith bottom, 6 November 2010.

Family Muraenidae Rafinesque, 1815.

Gymnothorax maderensis (Johnson, 1862) (Figure 2). Sharktooth Moray (English); Moréia-da-madeira, moreão amarelo (Portugal Portuguese); moréia portuguesa (Brazilian Portuguese); morena verde (Spanish).

Morphometric data are given in Table 2. The muraenid body is elongate, muscular, and laterally compressed; dorsal profile of head, above and behind eye, often raised due to strong head muscles; anterior nostril tubular, near snout tip, posterior nostril above or before eye, a simple pore or in a tube. The genus Gymnothorax presents the dorsal fin originating above and before the anus, the absence of molarifom teeth, jaws not prominently arched, teeth usually not exposed when mouth is closed; posterior nostril not in the shape of a tube; and gill opening usually the same color of body. Gymnothorax

Table 1. Morphometric data for Chlopsis dentatus, with source and number of specimens.

\begin{tabular}{|c|c|c|c|c|}
\hline Measurements & Present study, 1 & SEALE (1917), 1 & BÖHLKE \& SMITH (1968), 6 & Range \\
\hline \multicolumn{5}{|l|}{ Proportions } \\
\hline Total length (mm) & 85.2 & 100.0 & 95.9-198.5 & $85.2-198.5$ \\
\hline \multicolumn{5}{|l|}{ Percentage of total length } \\
\hline Head length & 13.6 & 13.0 & $12.0-14.0$ & $12.0-14.0$ \\
\hline Pre-anus distance & 29.8 & 31.0 & $32.0-35.0$ & $29.8-35.0$ \\
\hline Pre-dorsal-fin distance & 13.0 & ----- & $13.0-16.0$ & $13.0-16.0$ \\
\hline Body depth at anus & 4.2 & ----- & $4.0-6.8$ & $4.0-6.8$ \\
\hline \multicolumn{5}{|c|}{ Percentage of head length } \\
\hline Snout length & 24.1 & 28.4 & $25.0-27.7$ & $24.1-28.4$ \\
\hline Eye diameter & 9.5 & 12.9 & $9.5-16.0$ & $9.5-16.0$ \\
\hline Upper jaw length & 38.8 & 43.5 & $38.3-41.6$ & $38.3-43.5$ \\
\hline Interorbital width & 19.0 & ----- & $18.0-23.0$ & $18.0-23.0$ \\
\hline
\end{tabular}




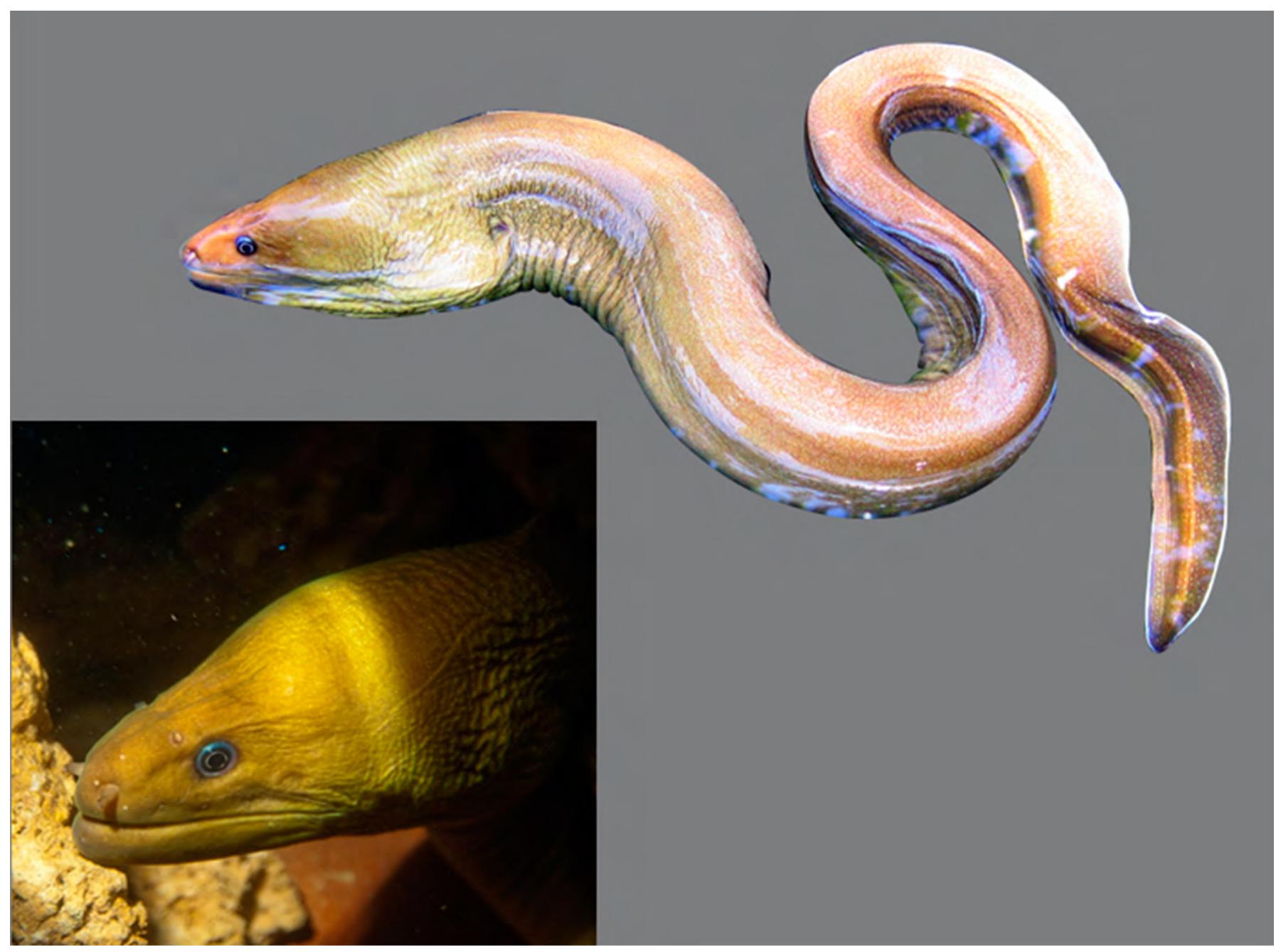

Figure 2. Gymnothorax maderensis, TAMAR 094, $770.3 \mathrm{~mm}$ TL. Insert: close up of a live fish at TAMAR aquarium. Photos by A. Carvalho-Filho.

maderensis can be separated from all other Atlantic congeners, except Gymnothorax bacalladoi Bohlke \& Brito, 1987, by the presence of serrate edges of the large triangular teeth (Figure 2D); from G. bacalladoi, it differs by the uniserial maxillary teeth, usually two branchial pores, and 149-158 vertebrae (versus biserial maxillary teeth, usually one branchial pore and 130-131 vertebrae). Both specimens collected by the TAMAR team from Bahia were covered by a lime-green slime that gives an overall bright lime-green color to live specimens (Figure 2C; see also a photograph of recent collected specimen in Williams et al. 2010). This coating easily disappears from the epidermis of specimens when handled. When this coating is removed, specimens are brownish overall, with some greenish and yellowish tinges on head, light yellow on tail, and minute, numerous, pale dots and/or vermiculation from upper head to tip of tail, more spaced posteriorly. There are

Table 2. Morphometric data for Gymnothorax maderensis, with source and number of specimens.

\begin{tabular}{|c|c|c|c|c|c|}
\hline Measurements & Present Study, 9 & JOHNSON (1862), 2 & BLACHE (1967), 2 & BÖHLKE et al. (1989), 14 & Range \\
\hline \multicolumn{6}{|l|}{ Proportions } \\
\hline Total length (mm) & $625-940$ & 912-1019 & $818-905$ & 499-1042 & 499-1042 \\
\hline \multicolumn{6}{|l|}{ Percentage of total length } \\
\hline Head length & $12.4-13.7$ & 12.2 & $11.6-12.1$ & $10.0-12.0$ & $10.0-13.7$ \\
\hline Pre-anal-fin distance & $51.9-56.3$ & - & $53.8-55.2$ & $50.0-54.0$ & $50.0-56.3$ \\
\hline Pre-dorsal-fin distance & $11.4-12.4$ & 11.0 & $11.0-11.1$ & $10.0-11.0$ & $10.0-12.4$ \\
\hline $\begin{array}{l}\text { Body depth at gill } \\
\text { opening }\end{array}$ & $8.6-11.6$ & 8.6 & $5.4-6.8$ & $6.2-8.7$ & $5.4-11.6$ \\
\hline Body depth at anus & $4.7-6.0$ & - & $4.9-5.4$ & $4.2-5.2$ & $4.2-6.0$ \\
\hline \multicolumn{6}{|l|}{ Percentage of head length } \\
\hline Snout length & $19.5-22.6$ & - & $17.2-22.8$ & $18.0-22.0$ & $17.2-22.8$ \\
\hline Eye diameter & $8.5-9.1$ & 6.6 & $7.1-8.1$ & $6.4-10.0$ & $6.4-10.0$ \\
\hline Upper jaw length & $38.8-47.2$ & - & $36.4-42.8$ & $37.0-45.0$ & $36.4-47.2$ \\
\hline Lower jaw length & $40.2-44.7$ & - & --- & $39.0-44.0$ & $39.0-44.7$ \\
\hline Interorbital width & $14.6-19.4$ & - & $13.8-14.1$ & $13.0-18.0$ & $13.0-19.4$ \\
\hline
\end{tabular}


a few dark, short, undulating lines present on underparts of head and anterior trunk. Fins are pale-edged. After preservation, the overall color becomes light tan to yellowish or dark brown, with the pale marks less evident but still well visible. For color variations see GÜNTHER (1870), BLACHE (1967), and BöHLKE et al. (1989). Some of our measurements widen the range of morphometric proportions of the species (Table 2 ), as head length, pre-anal-fin and pre-dorsal-fin distances, and depth of body (at gill opening and at anus). We consider these differences in proportions as characteristic of the Brazilian population and the wider ranges herein presented agree with those of other species of the genus, such as Gymnothorax saxicola Jordan \& Davis, 1891, G. ocellatus Agassiz, 1831, and G. miliaris (Kaup, 1856), among others (BÖHLKE et al. 1989). The identification of this species follows JoHNSON (1862), GÜNTHER (1870), Blache (1967), DoOley et al. (1985), BAUCHOt (1986), BÖHLKE et al. (1989), SMithVANiz \& Jelks (2014), Robertson \& VAN TASSEL (2015), SMITH \& McCosKer (2015), and SMITH (2016b).

Material examined: MNRJ 18604: 1, $877.2 \mathrm{~mm}$ TL, MNRJ 18605: 1, 803.6 mm TL, MNRJ 18961: 1, 883.2 mm TL, MNRJ 18963: 1, 625.0 mm TL, MNRJ 18964: 1, $655.4 \mathrm{~mm}$ TL, MNRJ 18981: 1, $940.2 \mathrm{~mm}$ TL, and MNRJ 18982: 1, 660.6 mm TL; all from off Bahia, Brazil, collector: Projeto REVIZEE, 1997; TAMAR 097: 1, $770.3 \mathrm{~mm}$ TL, and MZUSP 119853: 1, $743.1 \mathrm{~mm}$ TL, both from about 10 miles off Praia do Forte, (12 $36^{\prime} 96^{\prime \prime}$ S, 037 $53^{\prime} 78^{\prime \prime}$ W), Mata de São João, Bahia, Brazil, collector: G. Marcovaldi, depth 200 m, 13 February 2012.

The new records of Chlopsis dentatus and Gymnothorax maderensis expand the distribution of both species southwards along the Brazilian coast for several thousands of kilometres.

Chlopsis dentatus has a broad distribution, known from the western Indian Ocean (Mozambique and Kenya) and the Atlantic Ocean (SMith 1989a; Blache 1972). In the Western Atlantic, it is known from North Carolina to Florida (USA), Bermuda, the Caribbean (Cuba, Bahamas, Barbados, Curacao, Colombia, Dominican Republic, and the coast of Mexico) and off northern Brazil (SMITH 1989b; Menezes 2003; vouchers at the NMNH: e.g., 111595, 315438 and 426738, from Cuba, Bermuda and Curacao, respectively; and voucher at the MCZ: Ichthyology 100332, from 0308'30" N, 042 52'30" W, off northern Brazil). In the Eastern Atlantic $C$. dentatus occurs off the coast of Gabon, in the Gulf of Guinea, and around the Canary, Cape Verde and Madeira islands (SMITH 1989a; BlAche 1972). It is probably sympatric with C. olokun (Robins \& Robins, 1966), as reported by Blache (1972). The Eastern Atlantic distribution is also supported by several vouchers specimens deposited at the BMNH: e.g., BMNH 1994.11.1.477, 1994.11.1.481, and 1994.11.1.482, from Canary, Cape Verde, and Madeira islands, respectively; and vouchers at the MCZ: e.g. Ichthyology 70728, and 70730, from $15^{\circ} 27^{\prime} \mathrm{N}, 026^{\circ} 12^{\prime} \mathrm{W}$, off Cabo Verde Islands, and $02^{\circ} 54^{\prime}$ $\mathrm{S}, 008^{\circ} 06^{\prime} \mathrm{E}$, off Gabon. A single specimen collected from western Pacific (Solomon Islands) previously identified as C. dentatus by Smith (1989a) is, in fact, C. slusserorum Tighe \& McCosker, 2003 (Tighe et al. 2015).

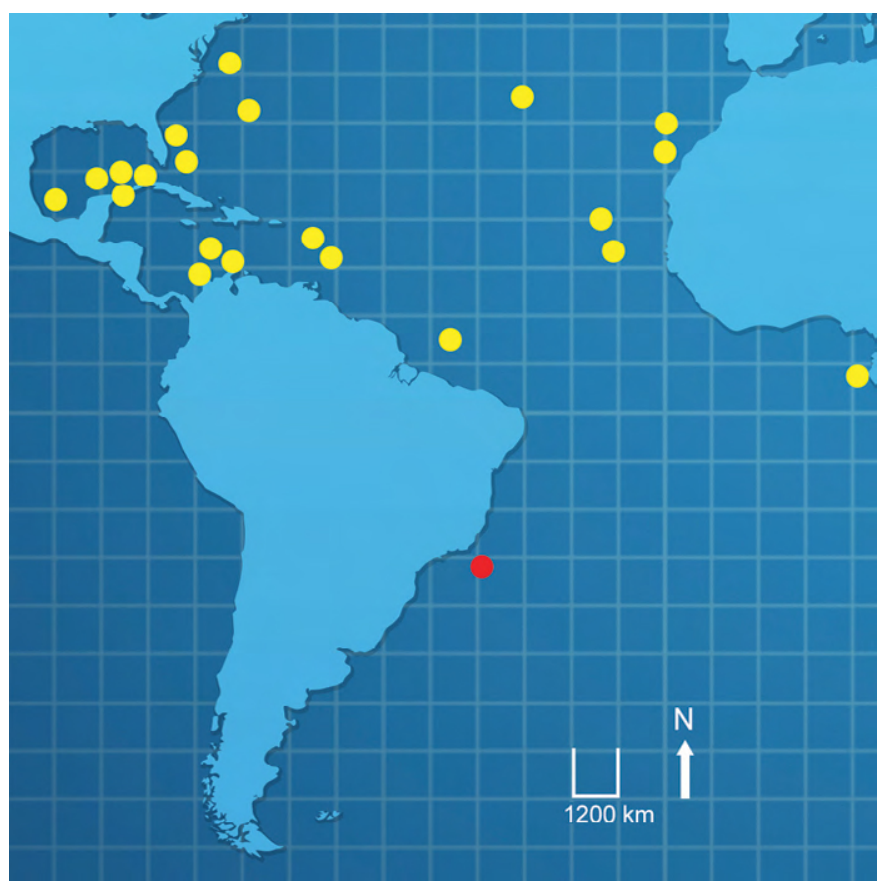

Figure 3. Chlopsis dentatus occurrences in Atlantic Ocean. Based on literature (SMITH 1989a and 1989b; BLACHE 1972; MENEZES 2003) and collections vouchers (BMNH: 1994.11.1.477, 1994.11.1.481, and 1994.11.1.482, from Canary, Cape Verde, and Madeira islands, respectively; MCZ: Ichthyology 100332, from $03^{\circ} 08^{\prime} 30^{\prime \prime} \mathrm{N}, 042^{\circ} 52^{\prime} 30^{\prime \prime} \mathrm{W}$, off northern Brazil; Ichthyology 70728 , and 70730 , from $15^{\circ} 27^{\prime} \mathrm{N}, 026^{\circ} 12^{\prime} \mathrm{W}$, off Cabo Verde Islands, and $02^{\circ} 54^{\prime} \mathrm{S}, 008^{\circ} 06^{\prime} \mathrm{E}$, off Gabon; NMNH: 111595,315438 and 426738, from Cuba, Bermuda and Curacao, respectively.Yellow spots, species previously known; red spot, MZUSP 233443 occurrence site.

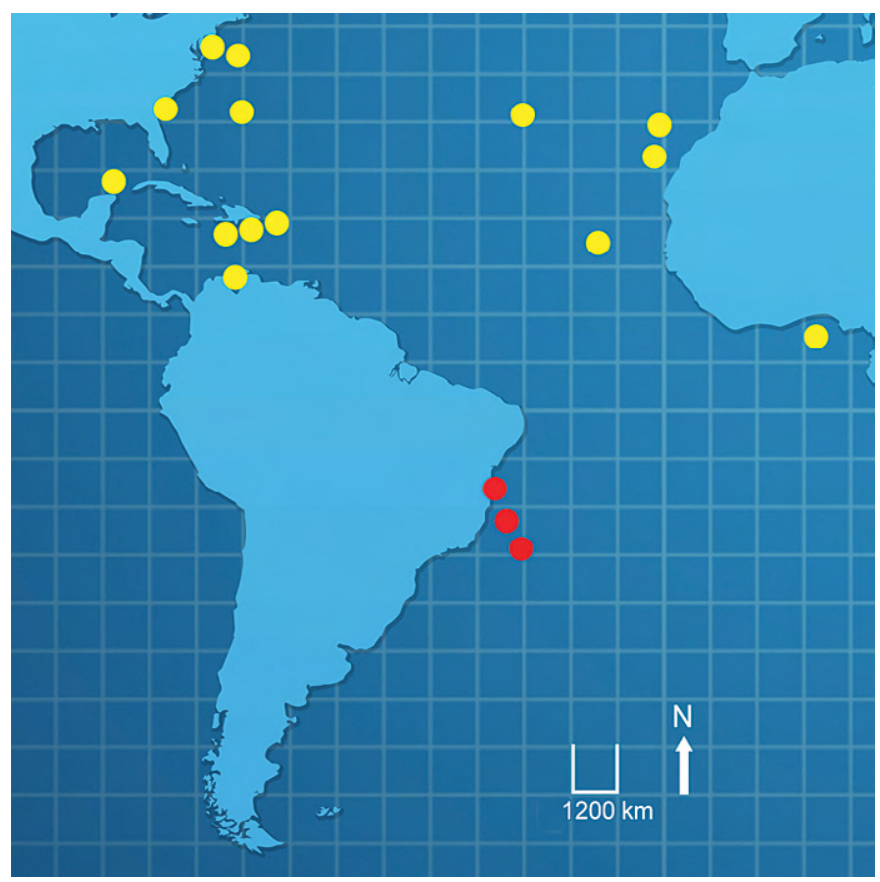

Figure 4. Gymnothorax maderensis occurrences in Atlantic Ocean. Based on literature (DOOLEY et al. 1985; BÖHLKE et al. 1989; WILLIAMS et al. 2010; SMITH-VANIZ \& JELKS 2014; ROBERTSON \& VAN TASSEL 2015; SMITH \& MCCOSKER 2015; MARTINS et al. 2005; OLAVO et al. 2007 and 2011; and PINHEIRO et al. 2015) and examined material. Yellow spots, species previously known records from Eastern and Northern Atlantic; red spots, Brazilian records. 
Previous occurrences of $C$. dentatus in Brazilian waters were reported by BONECKER et al. (2014), based only on leptocephali specimens from the same area of the adult recorded here, and by Menezes (2003) based on the above cited MCZ voucher (Ichthyology 100332). Thus, we report the occurrence of an adult $C$. dentatus in the southwestern Atlantic (Figure 3) which, along with the leptocephalus reported by BONECKER et al. (2014), extends the range of the species by ca. 3,300 km southwards along the Brazilian coast, from the previously reported southernmost occurrence locality (off Brazil, MCZ voucher as above).

Gymnothorax maderensis also has a broad range and was previously known in the Eastern Atlantic from Madeira, Cabo Verde, and Canary islands, and Gulf of Guinea (DoOley et al. 1985; BöHLKE et al. 1989). In the Western Atlantic it is known from Bermuda, North Carolina to Florida (USA), and the Caribbean region (Cuba, Puerto Rico, Virgin Islands, Anguilla, Antigua, Barbuda, Saba, Bonaire, and Curaçao) (WiLliams et al. 2010; SMITH-VANIZ \& JELKS 2014; RoBERTSON \& VAN TASSEL 2015; SMITH \& MCCOSKER 2015). Records from Brazil are from Bahia and Espírito Santo states, as presented by MARTINS et al. (2005), OlAvo et al. (2007, 2011), and PinHeiro et al. (2015). However, these authors do not present vouchers or details about the records, and thus, our work has significance in being the first vouchered occurrence data for this species in Brazil. Ignoring previous, unvouchered records, the range of this uncommon species in the Western Atlantic is extended by ca.6,200 km from the previously reported southernmost occurrence (Bonaire and Curaçao) (Figure 4).

\section{ACKNOWLEDGEMENTS}

The authors are grateful to the oceanographer, Guy Marcovaldi, head of TAMAR, for his support, help in the field, and shared knowledge; Domingos D. de Carvalho, Renildo D. de Carvalho, and Adriano J. Santos, captain and crew of the TAMAR vessel; the two anonymous reviewers and editors for their suggestions and corrections of the manuscript; Michel Giannetti, Aléssio Datovo, and Paulo A. Buckup for their help with MZUPS and MNRJ collections; and Frederico Tâmega and Carlos E. L. Ferreira for their data, support, and help with the Chlopsis specimen.

\section{LITERATURE CITED}

BAUCHOT, M.L. 1986. Muraenidae; pp. 537-544, in: P.J.P. WhiteHEAD, M.-L. BAUCHOt, J.-C. HuREAU, J. NiELSEN \& E. TORTONESE (eds.). Fishes of the North-eastern Atlantic and the Mediterranean, Volume II, UNESCO, Paris.

Bernardes, R.A., J.L. Figueiredo, A.R. Rodrigues, L.G. Fischer, C.M.VOoren, M. HAIMOVICI, \& C.L.D.B. Rossi-WomgtSCHOWSKI. 2005. Peixes da Zona Econômica Exclusiva da Região Sudeste-Sul do Brasil; levantamento com armadilhas, pargueiras e rede de arrasto de fundo. Editora da Universidade de São Paulo. 295 pp.

Betancur-R., R., E. Wiley, N. Bailly, M. Miya, G. Lecointre \& G. Ortí. 2014. Phylogenetic Classification of Bony Fishes. Version 3. Accessed at http://www.deepfin.org/Classification_v3.htm, 15 June 2016.
BLACHE, J. 1972. Larves leptocéphales des poissons anguilliformes dans de Golfe de Guinée (Zone Sud), $2^{\mathrm{e}}$ note: les espèces adultes de Xenocongridae et lerus larves. Cahiers ORSTOM, Série Océanographie 10(3): 219-241.

Blache, J, 1967. Contribution à la connaissance des poissons Anguilliformes de la côte occidentale d'Afrique. Cinquiéme note. Le genre Gymnothorax Bloch 1795. Bulletin de l'Institut Fondamental d'Afrique Noire (Série A) Sciences Naturelles, 29(4): $1695-1705$.

BMNH. 2016. British Museum of Natural History collection. Accessed at http://data.nhm.ac.uk/dataset/56e711e6-c847-4f99915a-6894bb5c5dea/resource/05ff2255-c38a-40c9-b657-4ccb55 ab2feb?q=Chlopsis+dentatus, 16 April 2016.

BöHlKe, E.B. (ed.). 1989. Fishes of the western North Atlantic. Part 9. Volume 1: Anguilliformes and Saccopharyngiformes. Sears Foundation for Marine Research, Memoir 1: 655 pp.

BöHLKe, E.B., J.E. McCosker \& J.E. BöHLKe. 1989. Family Muraenidae; pp. 104-206, in: E.B. BöHLKE (ed.). Fishes of the Western North Atlantic. Part 9. Volume 1: Anguilliformes and Saccopharyngiformes. Sears Foundation for Marine Research, Memoir 1.

BöHLKE, J.E. \& D.G. SMITH. 1968. A new xenocongrid eel from the Bahamas, with notes on other species in the family. Proceedings of the Academy of Natural Sciences of Philadelphia 120 (2): 25-43. http://www.jstor.org/stable/4064632

Bonecker, A.C.T., C.A.P. NAMiki, M.S. CASTRo \& P.N. Campos. 2014. Catálogo dos estágios iniciais de desenvolvimento dos peixes da bacia de Campos. Série zoologia: guias e manuais de identificação. Curitiba: Sociedade Brasileira de Zoologia. 295 pp. doi: 10.7476/9788598203102

Carvalho-Filho, A., G. Marcovaldi, C.L.S. Sampaio, M.I.G. Paiva \& L.A.G. DuARTE. 2009. First report of rare pomfrets (Teleostei: Bramidae) from Brazilian waters, with a key to Western Atlantic species. Zootaxa 2290: 1-26. http://www.mapress.com/zootaxa/ 2009/f/z02290p026f.pdf

Carvalho-Filho, A., G. Marcovaldi, C.L.S. Sampaio, M.I.G. PAIVA \& L.A.G. DUARTE. 2010. First report of Aulopus (Teleostei: Aulopidae) from Southwestern Atlantic, with a review of records and a key to Western Atlantic Aulopoidei species. Zootaxa 2628: 27-42. http://www.mapress.com/zootaxa/2010/f/zt02628p042. pdf

Carvalho-Filho, A., G. Marcovaldi, C.L.S. Sampaio \& M.I.G. PAIVA. 2011. First report of Macruronus novaezelandiae (Gadiformes: Merluccidae: Macruroninae) from Atlantic tropical Waters. Marine Biodiversity Records 4: e49. doi: https://doi. org/10.1017/S1755267211000431

CAstro, M.S. \& A.C.T. BONECKer. 2006. Anguilliformes: pp. 40-73, in: A.C.T. BONECKer, \& M.S. CAStro (eds.). Atlas de larvas de peixes da região central da Zona Econômica Exclusiva brasileira. Série Livros/Documentos REVIZEE Score Central. Rio de Janeiro: Museu Nacional.

DoOLEY, J.K, J. VAN TASSELL \& A. BRITO. 1985. An annotated checklist of the shorefishes of the Canary Islands. American Museum Novitates 2824: 1-49. http://hdl.handle.net/2246/5235

Günther, A. 1870. Catalogue of the Physostomi, containing the families Gymnotidae, Symbranchidae, Muraenidae, Pegasidae and of the Lophobranchii, Plectognathi, Dipnoi, Ganoidei, Chondropterygii, Cyclostomata, Leptocardii, in the British Museum. London: Taylor and Francis. xxv +549 pp.

JoHnson, J.Y. 1862. Descriptions of some new genera and species of fishes obtained at Madeira. Proceedings of the Zoological Society of London 1862: 167-180. http://www.biodiversitylibrary.org/ item/90953

Martins, A.S., G. Olavo \& P.A.S. Costa. 2005. Recursos demersais capturados com espinhel de fundo no talude superior da região entre Salvador (BA) e Cabo de São Tomé (RJ); pp. 109-128, in: P.A.S. Costa, A.S. Martins \& G. Olavo. Pesca e potenciais de exploração de recursos vivos na região central da Zona Econômica 
Exclusiva Brasileira. Série Livros, Documentos REVIZEE/Score Central, Livro 13. Museu Nacional: Rio de Janeiro. http://www. mar.mil.br/secirm/documentos/revizee/score-central-vol13.pdf_

MCZ. 2016. Museum of Comparative Zoology collection. Accessed at http://mczbase.mcz.harvard.edu/SpecimenResults.cfm, 16 April 2016.

Melo, M., G. Nunan, A. Braga \& P.A.S. Costa. 2009. The deep-sea Anguilliformes and Saccopharyngiformes (Teleostei: Elopomorpha) collected on the Brazilian continental slope, between $11^{\circ}$ and $23^{\circ}$ S. Zootaxa 2234: 1-20. http://www.mapress.com/zootaxa/ 2009/f/zt02234p020.pdf

Menezes, G.M., O. Tariche, M.R. Pinho, A. Duarte, A. Fernandes \& M.A. Авогм. 2004. Annotated list of fishes caught by the R/V Arquipélago off the Cape Verde archipelago. Arquipélago: Life and Marine Sciences 21(A): 57-71.

Menezes, N.A., P.A. Buckup, J.L. Figueiredo \& R.L. Moura (eds.). 2003. Catálogo das espécies de peixes marinhos do Brasil. São Paulo: Museu de Zoologia da Universidade de São Paulo. 159 pp.

Menezes, N.A. 2003. Muraenidae; pp. 33-34, in: N.A. Menezes, P.A. Buckup, J.L. Figueiredo \& R.L. Moura (eds). Catálogo das espécies de peixes marinhos do Brasil. São Paulo: Museu de Zoologia da Universidade de São Paulo.

Menezes, N.A. 2003. Chlopsidae; pp. 32, in: N.A. Menezes, P.A. Buckup, J.L. Figueiredo \& R.L. Moura (eds). Catálogo das espécies de peixes marinhos do Brasil. São Paulo: Museu de Zoologia da Universidade de São Paulo.

Mincarone, M. M., J. G. Nielsen \& P.A.S. Costa. 2008. Deepsea ophidiiform fishes collected on the Brazilian continental slope, between $11^{\circ}$ and $23^{\circ}$ S. Zootaxa 1770: 41-64. http://www. mapress.com/zootaxa/2008/f/z01770p064f.pdf_

NMNH. 2016. National Museum of Natural History collection. Accessed at http://collections.nmnh.si.edu/search/fishes, 16 April 2016.

Olavo, G., P.A.S. Costa \& A.S. Martins. 2007. Estrutura de comunidades de peixes recifais na plataforma externa e talude superior da costa central brasileira: diversidade e distribuição batimétrica; pp. 15-44, in: O. CostA \& A.S. MARTins (eds). Biodiversidade da fauna marinha profunda na costa central brasileira, Documentos REVIZEE/Score Central, Livro 24. Rio de Janeiro: Museu Nacional. http://www.mar.mil.br/secirm/documentos/revizee/scorecentral-vol24.pdf

Olavo, G., P.A.S. Costa, A.S. MARTins \& B.P. Ferreira. 2011. Shelfedge reefs as priority areas for conservation of reef fish diversity in the tropical Atlantic. Aquatic Conservation: Marine and Freshwater Ecosystems 21(2): 199-209. doi: 10.1002/aqc.1174_

Paiva, C.C., M.E. Araujo, R.A. CAires, R. SAlles, R.S. Medeiros \& T.M.C. Lotufo. 2011. Six new records of deep-sea fish off northeastern Brazil. Marine Biodiversity Records 4: e9. doi: 10.1017/ S1755267210001247

Pinheiro H.T., E. Mazzei, R.L. Moura, G.M. Amado-Filho, A. Carvalho-Filho, A.C. Braga. 2015. Fish biodiversity of the Vitória-Trindade Seamount Chain, Southwestern Atlantic: an updated database. PLoS ONE 10(3): e0118180. doi: https://doi. org/10.1371/journal.pone. 0118180

Robertson, D.R. \& J. VAN TASSELL. 2015. Shorefishes of the Greater Caribbean: online information service. Version 1.0. Smithsonian Tropical Research Institute, Balboa. Panama. Accessed at http:// biogeodb.stri.si.edu/caribbean/en/pages, 15 April 2016.
RoBins, C.R. \& C.H. RoBINs. 1966. Xenoconger olokun, a new xenocongrid eel from the Gulf of Guinea. Studies in Tropical Oceanography 4(1): 117-124. http://scholarlyrepository.miami.edu/trop_ocean/4

RoBINS, C.H. \& C.R. RoBINs. 1967. Biological investigations of the deep sea. 29. The xenocongrid eel Chlopsis bicolor in the western North Atlantic. Bulletin of Marine Science 17(1): 232-248. http://www.ingentaconnect.com/content/umrsmas/ bullmar/1967/00000017/00000001/art00013

SABAJ-PÉRez, M.H. (ed.). 2014. Standard symbolic codes for institutional resource collections in herpetology and ichthyology: an online reference. Version 5.0 (22 September 2014). Washington, DC: American Society of Ichthyologists and Herpetologists. Accessed at http://www.asih.org, 15 April 2016.

Seale, A. 1917. New species of apodal fishes. Bulletin of the Museum of Comparative Zoology at Harvard College 61(4): 79-94. http:// www.biodiversitylibrary.org/item/25424_

SMITH, D.G. 1989a. Family Chlopsidae: pp. 72-97, in: E.B. BöHLKE (ed.). Fishes of the western North Atlantic. Part 9. Volume 1: Anguilliformes and Saccopharyngiformes. Sears Foundation for Marine Research, Memoir 1.

SMITH, D.G. 1989b. Family Chlopsidae: pp. 933-942, in: E.B. Böhlke (ed.). Fishes of the western North Atlantic. Part 9. Volume 2: Leptocephali. Sears Foundation for Marine Research, Memoir 2.

Smith, D.G. 2016a. Family Chlopsidae: pp. 1611-1613, in: K.E. CARpenter \& N. De Angelis (eds.). The living marine resources of the eastern central Atlantic. Volume 3, bony fishes, part 1 (Elopiformes to Scorpaeniformes). FAO species identification guide for fisheries purposes. Rome: FAO.

Sмith, D.G. 2016b. Family Muraenidae: pp. 1614-1642, in: K.E. CARPENTER \& N. De Angelis (eds.). The living marine resources of the eastern central Atlantic. Volume 3, bony fishes, part 1 (Elopiformes to Scorpaeniformes). FAO species identification guide for fisheries purposes. Rome: FAO.

SMITH, D.G. \& J.E. MCCoskeR. 2015. Gymnothorax maderensis. The IUCN Red List of threatened species 2015: e.T190250A1 946099. doi: 10.2305/iucn.uk.2015-2.rlts.t190250a1946099.en

Smith-VANIZ, W.F \& H.L. JelKs. 2014. Marine and inland fishes of St. Croix, U.S. Virgin Islands: an annotated checklist. Zootaxa 3803: 001-120. doi: 10.11646/zootaxa.3803.1.1

Tighe, K.A., J.J. Pogonoski,, Y. Hibino, H-C. Ho \& Q.V. NguYen. 2015. Three new species of the genus Chlopsis (Anguilliformes: Chlopsidae) from the Indo-Pacific. Zootaxa 4060: 019-029. doi: 1011646/zootaxa.4060.1.4

Tighe, K.A. \& J.E. McCosker. 2003. Two new species of the genus Chlopsis (Teleostei: Anguilliformes: Chlopsidae) from the southwestern Pacific. Zootaxa 236: 1-8. doi: 10.11646/zootaxa.236.1.1

Williams J.T, K.E. Carpenter, J.L. Van Tassell, P. HoetJes, W. TOLLER et al. 2010. Biodiversity assessment of the fishes of Saba Bank Atoll, Netherlands Antilles. PLoS ONE 5(5): e10676. doi: 10.1371/journal.pone.0010676

Authors' contributions: MIGP collected, fixed, and prepared the Gymnothorax maderensis specimens. ACF made the analysis and wrote the text.

Received: 7 May 2016

Accepted: 26 January 2017

Academic editor: Hudson Pinheiro 


\section{APPENDIX}

Table A1. Literature sources and vouchers for Figure 3, Chlopsis dentatus occurrences in Atlantic Ocean.

\begin{tabular}{|c|c|c|c|c|c|}
\hline Source, vouchers & Literature & Vouchers & Locality & Latitude & Longitude \\
\hline Yellow spots & & BMNH 1994.11.1.477 & Canary Isl. & $27^{\circ} 56^{\prime} \mathrm{N}$ & $37^{\circ} 45^{\prime} \mathrm{W}$ \\
\hline \multirow[t]{4}{*}{ Eastern Atlantic } & BLACHE 1972; SMITH 1989a. & BMNH 1994.11.1.482 & Madeira Isl. & $31^{\circ} 23^{\prime} \mathrm{N}$ & $29^{\circ} 49^{\prime} \mathrm{W}$ \\
\hline & & BMNH 1994.11.1.481 & Cape Verde & $17^{\circ} 39^{\prime} \mathrm{N}$ & $25^{\circ} 19^{\prime} \mathrm{W}$ \\
\hline & & MCZ 70728 & Cape Verde & $15^{\circ} 27^{\prime} \mathrm{N}$ & $26^{\circ} 12^{\prime} \mathrm{W}$ \\
\hline & & MCZ 70730 & Gabon & $02^{\circ} 54^{\prime} \mathrm{S}$ & $08^{\circ} 06^{\prime} \mathrm{E}$ \\
\hline \multirow[t]{3}{*}{ Northwestern Atlantic } & MENEZES 2003; ROBINS \& ROBINS 1967; Smith 1989a, 1989b & MCZ 100332 & Brazil & $03^{\circ} 08^{\prime} \mathrm{N}$ & $42^{\circ} 52^{\prime} \mathrm{W}$ \\
\hline & & NMNH 315438 & Bermuda & $32^{\circ} 00^{\prime} \mathrm{N}$ & $63^{\circ} 53^{\prime} \mathrm{W}$ \\
\hline & & NMNH 426738 & Curacao & $12^{\circ} 06^{\prime} \mathrm{N}$ & $68^{\circ} 53^{\prime} \mathrm{W}$ \\
\hline \multicolumn{6}{|l|}{ Red spot } \\
\hline Southwestern Atlantic & BONECKER et al. 2014; this work. & MZUSP 119852 & Rio de Janeiro & $23^{\circ} 18^{\prime} \mathrm{S}$ & $41^{\circ} 17^{\prime} \mathrm{W}$ \\
\hline
\end{tabular}

Table A2. Literature Sources and Vouchers for Figure 4, Gymnothorax maderensis occurrences in Atlantic Ocean.

\begin{tabular}{|c|c|c|c|c|c|}
\hline Source, Vouchers & Literature & Vouchers & Locality & Latitude & Longitude \\
\hline \multicolumn{6}{|l|}{ Yellow spots } \\
\hline Eastern Atlantic & $\begin{array}{l}\text { BAUCHOT 1986; BLACHE 1967; BÖHLKE et al. 1989; DOOLEY et al. } \\
\text { 1985; GÜNTHER 1870; SMITH \& MCCOSKER } 2015\end{array}$ & & & & \\
\hline Northwestern Atlantic & $\begin{array}{l}\text { BÖHLKE et al. 1989; ROBERTSON \& VAN TASSEL 2015; SMITH \& } \\
\text { MCCOSKER 2015; SMITH-VANIZ \& JELKS 2014; WILLIAMS et al. } \\
2010\end{array}$ & & & & \\
\hline \multicolumn{6}{|l|}{ Red spots } \\
\hline \multirow[t]{4}{*}{ Southwestern Atlantic } & $\begin{array}{l}\text { MARTINS et al. 2010; OLAVO et al. 2007, 2011; PINHEIRO et al. } \\
\text { 2015; this work. }\end{array}$ & & & & \\
\hline & & MNRJ 18604 & Bahia & No data & No data \\
\hline & & TAMAR 097 & Bahia & $12^{\circ} 36^{\prime} \mathrm{S}$ & $37^{\circ} 53^{\prime} \mathrm{W}$ \\
\hline & & MZUSP 119853 & Bahia & $12^{\circ} 36^{\prime} \mathrm{S}$ & $37^{\circ} 53^{\prime} \mathrm{W}$ \\
\hline
\end{tabular}

